\title{
Inguinal Fistula by Suture Granuloma Post Microsurgical Varicocelectomy: A Rare Entity
}

\section{Mikrocerrahi Varikoselektomi Sonrası Sütür Granülomu ile Oluşan İnguinal Fistül: Nadir Bir Olgu}

\author{
Ayhan Karakose (D, Yasin Yitgin (1) \\ Department of Urology, Istinye University Faculty of Medicine, Istanbul, Turkey \\ Cite as: Karakose A, Yitgin Y. Inguinal fistula by suture granuloma post microsurgical varicocelectomy: a rare entity. \\ Grand J Urol 2022;2(1):42-4.
}

Submission date: 16 July $2021 \quad$ Acceptance date: 09 October $2021 \quad$ Online First: 20 October 2021

Publication date: 20 January 2022

Corresponding Author: Yasin Yitgin / Istinye University Faculty of Medicine, Department of Urology, Istanbul, Turkey / yasinyitgin@hotmail.com / ORCID ID: 0000-0003-1111-6941

\begin{abstract}
Varicocele is dilatation and tortuosity of the vessels in the pampiniform plexus of spermatic cord and occurs in $11.7 \%$ of adult men. Varicocelectomy may lead to various complications such as hydrocele, testicular atrophy, haematoma, infection, damage of nerves and recurrence. A 22-year-old man presented after varicocelectomy with a rare postoperative complication of a fistula. The fistula tract was removed en bloc. The patient had a history of varicocelectomy, suggesting suture reaction. The fact that it is a rare complication of varicocelectomy makes our case interesting.
\end{abstract}

Keywords: varicocele, inguinal fistula, suture foreign body, suture granuloma, varicocele surgery

Öz

Varikosel, spermatik kord damarlarının anormal genişlemesi ve kıvrımlaşması olup yetişkin erkeklerin \%11.7'sinde görülür. Varikoselektomi ameliyatı hidrosel, testis atrofisi, hematom, enfeksiyon, sinir hasarı ve nüks gibi çeşitli komplikasyonlara yol açabilir. 22 yaşında erkek hasta varikoselektomi sonrası kasık fistülü gelişmesi sonrası varikoselektominin nadir bir komplikasyonu ile başvurdu. Fistül traktı en blok halinde çıkarıldı. Hastanın sütür reaksiyonunu düşündüren varikoselektomi öyküsü vardı. Olgumuz varikoselektomi sonrası nadir görülen bir komplikasyon olması nedeniyle ilginçtir.

Anahtar kelimeler: varikosel, inguinal fistül, sütür yabancı cisim, sütür granülomu, varikosel cerrahisi 


\section{Introduction}

Varicocele is dilatation and tortuosity of the vessels in the pampiniform plexus of spermatic cord, while $11.7 \%$ of adult men and $25.4 \%$ of men with abnormal semen analysis have varicocele. Also, the most common correctable cause of male infertility is varicocele. It affects 19 to $41 \%$ of men with primary, and 45 to $81 \%$ of men with secondary infertility [1].

Treatment of varicocele has been the subject of discussion in recent years. Many studies have shown that surgical varicocelectomy significantly improves semen parameters not only in men with clinical varicoceles, but also in men with nonobstructive azoospermia [2].

Inguinal varicocelectomy may lead to several complications including hydrocele which is the most frequent adverse postoperative outcome occurring in 3\% of patients followed by testicular atrophy, recurrence, haematoma and infection. Other complications include damage to the ilioinguinal, genitofemoral, or obturator nerves. These complications are significantly more common in non-microsurgical methods $[3,4]$.

In this report, we present a rare case of fistula occurring after microsurgical varicocelectomy and extending from the spermatic canal up to the skin of inguinal area and led to persistent wound formation. We aimed to emphasize the risk of fistula formation after varicocelectomy and to share our experience in the treatment of this complication.

\section{Case}

A 22-year-old male patient presented to urology department of our hospital with a rare surgical complication developed one year after bilateral varicocelectomy. The patient complained of a persistent subcutaneous inguinal swelling that intermittently discharged fluid through the skin. Varicocelectomy had been performed by a different surgeon with open microsurgery in the subinguinal region on both sides.

During physical examination, we detected bilateral subinguinal incision scar, a stiff palpable fistula tract extending from the inguinal canal to skin and an oozing purulent discharge. Ultrasonography (US) demonstrated a $17-\mathrm{mm}$ long 5-mm thick hypoechoic tract extending from the spermatic canal to the skin (Figure 1A). Blood levels of acute phase reactants were within normal ranges.

The operation was started using the previous incision line. A catheter was placed into the fistula tract which was freed from surrounding tissues by dissections (Figures 1B-C). At the junction of the spermatic cord and the fistula tract, silk suture materials causing granulomatous inflammatory reaction were detected. The fistula tract was removed en bloc. After complete excision of the fistula tract, and 2 pre-tied silk sutures were removed (Figure 1D). Pathological examination showed inflammatory granuloma characterised by giant-cell reaction (Figure 2). There was no recurrence of the fistula or the presence of additional findings during the 6-month postoperative follow-up.

\section{Discussion}

Varicocele can be treated using methods such as macroscopic
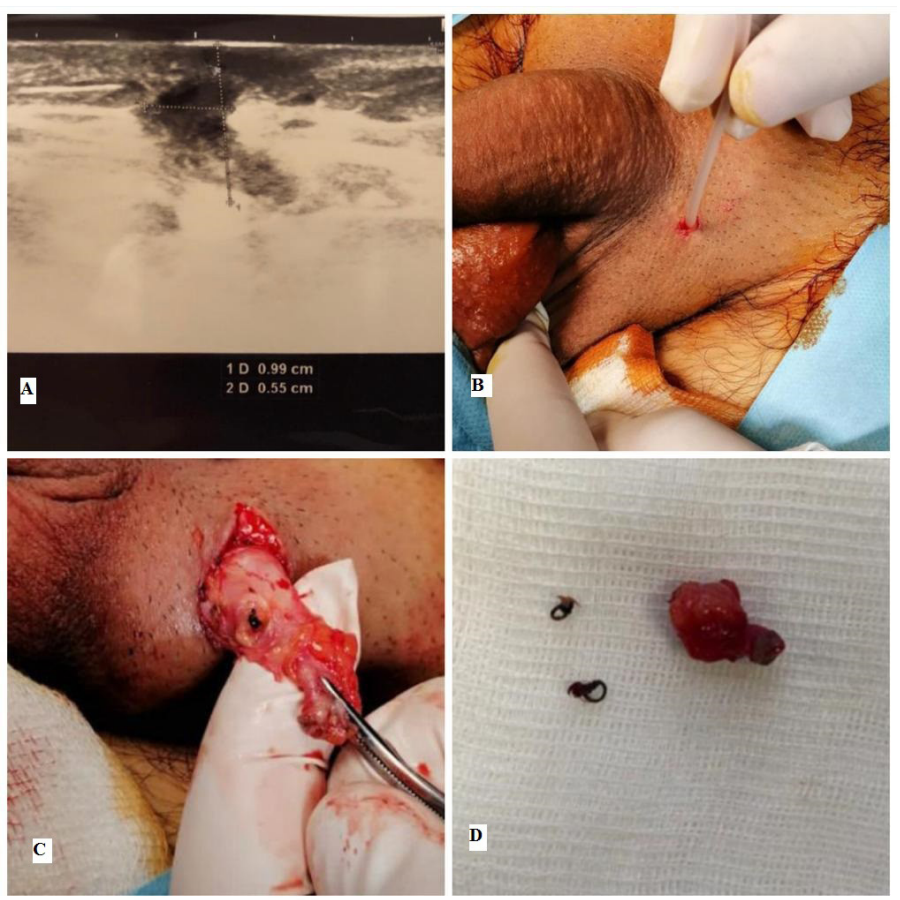

Figure 1.A- Ultrasound image of the fistula tract B- A catheter was placed into the fistula C- Silk sutures and granuloma D- En-block fistula tract and total sutures removed
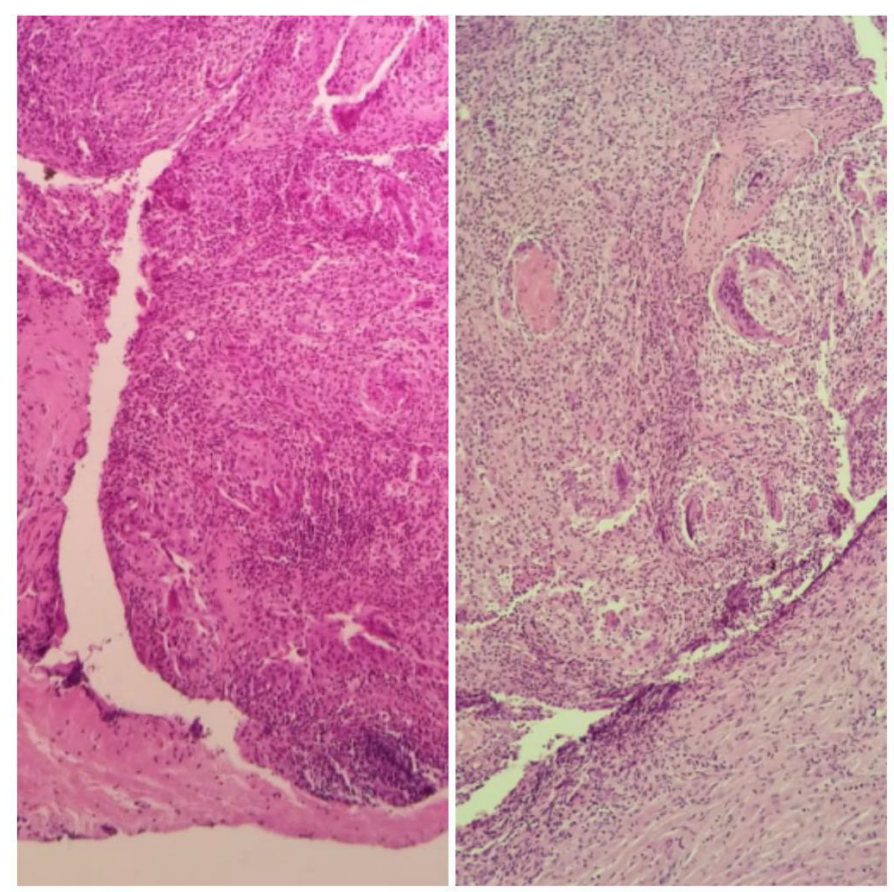

Figure 2. Microscopic view of fistula and inflammatory giant cells (H-E x 100)

or microscopic open surgery, laparoscopic surgery, embolization and sclerotherapy. It has been reported that complications such as recurrence and hydrocele are the least common after microsurgical varicocelectomy among varicocele treatment methods. However, it was stated that there was no significant difference in hematoma and infection rates between varicocele treatment methods [5].

There is no available data in the literature regarding the incidence of inguinal fistula after varicocele surgery. In our case, the patient developed inguinal fistula caused by suture granuloma 
which occurred after microsurgical inguinal varicocelectomy.

A suture granuloma is a rare surgical complication. It is an inflammatory, benign and granulomatous lesion that develops as a foreign body reaction to non-absorbable suture material at the surgery site. It may manifest as erythema, swelling, pain and leakage from the incision line. Silk suture, which is produced from silkworm larva and consists of protein fibers, is the most common non-absorbable suture material used. This silk suture is slowly degraded in the tissue over 2 years [6]. In the early postoperative period, an inflammation along the suture line can cause suppuration and sinus formation. However, a delayed inflammatory reaction of the suture is rare [7]. The variable time interval between the postoperative development of suture granuloma and subsequent formation of fistula has been reported by different authors as 2 years or few months to years [8,9]. In our case, this time interval was one year.

The pathogenesis of suture granuloma involves development of two succesive reactions. Initial reaction in the tissue reflects the severity of injury caused by the passage of the needle, and then after the initial reaction has subsided, the suture material causes a specific inflammatory reaction [8].

To our knowledge, we are presenting the first case of suture granuloma with inguinal fistula developed after microsurgical inguinal varicocelectomy, which therefore makes our case interesting.

In conclusion, we recommend the use of absorbable sutures or metallic surgical clips in varicocele surgeries to avoid such complications.

Ethics Committee Approval: N / A.

Informed Consent: An informed consent was obtained from the patient.

Publication: The results of the study were not published in full or in part in form of abstracts.

Peer-review: Externally and internally peer-reviewed.

Authorship Contributions: Any contribution was not made by any individual not listed as an author. Concept - YY.; Design - YY.; Supervision - AK.; Resources - AK.; Materials - AK.; Data Collection and/or Processing - AK.; Analysis and/or Interpretation - YY.; Literature Search - YY.; Writing - YY.; Critical Review - AK.

Conflict of Interest: The authors declare that they have no conflict of interest.

Financial Disclosure: The authors have declared that they did not receive any financial support for the realization of this study.

\section{References}

[1] Agarwal A, Deepinder F, Cocuzza M, Agarwal R, Short RA, Sabanegh E, et al. Efficacy of varicocelectomy in improving semen parameters: new meta-analytical approach. Urology 2007;70:532-8. https://doi.org/10.1016/j.urology.2007.04.011.

[2] Esteves SC, Miyaoka R, Roque M, Agarwal A. Outcome of varicocele repair in men with nonobstructive azoospermia: systematic review and meta-analysis. Asian $\mathrm{J}$ Androl 2016;18:246-53. https://doi.org/10.4103/1008-682X.169562.

[3] Amelar RD. Early and late complications of inguinal varicocelectomy. J Urol 2003;170:366-9. https://doi.org/10.1097/01.ju.0000074975.79734.17.

[4] Wang J, Xia SJ, Liu ZH, Tao L, Ge JF, Xu CM, et al. Inguinal and subinguinal micro-varicocelectomy, the optimal surgical management of varicocele: a meta-analysis. Asian J Androl 2015; 17:74-80. https://doi.org/10.4103/1008-682X.136443.

[5] Çayan S, Orhan I, Akbay E, Kadıŏlu A. Systematic review of treatment methods for recurrent varicoceles to compare post-treatment sperm parameters, pregnancy and complication rates. Andrologia 2019;51:e13419.

https://doi.org/10.1111/and.13419.

[6] Eryilmaz R, Demir M, Aslan R. Rare complication of varicocelectomy: Suture granuloma. Andrologia 2019;51;e13256. https://doi.org/10.1111/and.13256.

[7] Javalgi AP, Arakeri SU. Post thyroidectomy suture granuloma: a cytological diagnosis. J Clin Diagn Res 2013;7:715-7. https://doi.org/10.7860/JCDR/2013/5366.2890.

[8] Chung YE, Kim EK, Kim MJ, Yun M, Hong SW. Suture granuloma mimicking recurrent thyroid carcinoma on ultrasonography. Yonsei Med J 2006;47:748-51. https://doi.org/10.3349/ymj.2006.47.5.748.

[9] Karaköse A, Alp T, Güner ND, Çıtlak MB, Aydın S. The place of andrological cases in our general urology practice. Turk J Urol 2010;36:49-54. https://turkishjournalofurology.com/EN/march-2010-002. 